\title{
Note
}

\section{Bargaining in Correctional Institutions: Restructuring the Relation between the Inmate and the Prison Authority}

The recent wave of prison riots ${ }^{1}$ coupled with increasing activity by more "politicized" inmates" compels a reassessment of patterns of organization within correctional institutions. The following discussion attempts to develop a framework for understanding the system of control within prisons, and suggests a means of using that system of control to achieve more effectively the subtle and often incompatible goals of rehabilitation, institutional order, and protection from arbitrary punishment. ${ }^{3}$ It may also have implications for other

1. An increasing number of strikes, work stoppages, and "symbolic" disturbances may lic behind the more visible violence. In fact, as inmates have become better organized, they have been able to control their protests to gain maximum publicity while minimizing the likclihood of violent reprisal. See, e.g., N.Y. Times, Oct. 3, 1971, at 60, col. 1.

2. See, e.g., Roberts, Mood of Protest, Often Highly Political and Radical, Emerges in Nation's Prisons, N.Y. Times, Sept. 19, 1971, at 1, col. 1, reporting on a scries of intervicws with prisoners, wardens, and lawyers around the comtry. The survey reveals that many prisoners are organizing themselves with explicitly political motives. Si't also N.X. Times, Sept. 16, 1971, at 49, col. 1 .

3. Institutional order may be defined as the maintenance of inmates' safety and the institution's security from escapes or riots. While institutional security is fairly easy to measure, other goals are more difficult to define because opinions differ about what qualifies as "rehabilitation," "safety," or "arbitrary punishment" within an cnvirontntut in which rehabilitation is impossible to measure, safety is always relative, and punisliment is in the nature of the institution. Courts have occasionally issued broad directives, but specific standards are difficult to formulate. See, e.g., Landman v. Peyton, 370 1F.2d 195 (4th Cir. 1966), cert. denied, 388 U.S. 920 (1967) (inmates' right to be protected from capricious actions of guards); Holt v. Sarver, 300 F. Supp. 825 (E.D. Ark. 1969) (inmates" right to personal safety from other inmates); cf. Covinton v. Harris, 419 F.2d 617 (D.C. Cir. 1969) (inmates' right to treatment in mental hospital).

Much of the now classic literature on corrections assumes that institutional goals of "custody" and "security" are at odds with what might be viewed as more "himane" goals of rehabilitation and protection from arbitrary punishment. See, e.g., Cresscy, Limitations of Organization of Treatment in a Modern Prison, in THEonericut Sruvit's in Soctal Organization of the P'Rison 78, 93 (Social Science Rescarch Council cd. 1960) (lamphlet 15) [hereinafter cited as Theoretical Studies]. See generally D. ClemMik, THE prison Community (1940); D. Glaser, The Effectiveness of a l'Rison and parote System (1964); T. Mathiesen, Tile Defenses of The Wenk (1965). According to this general view, if we are ever to create institutions which genuincly promote such goals as rehabilitation and freedom from arbitrary punishment within the prison, then we must curtail pursuit of such aims as custody and sccurity. But this view assumes that the institution somehow has goals of its own, divorced from the political forces in society which shape it. A more pragmatic approach might take as given the fact that the public, as expressed through politicians and administrators, will insist upon a certain amount of custody and security from its prisons. Thus the aim for the foresecable future would be to maximize the fulfillment of rehabilitation and protection from arbitrary punish. ment without sacrificing custody and security. This Note will suggest that these dif. ferent goals might not be so incompatible as has previously been assumed. 
"total institutions"' such as schools, mental hospitals, and reformatories where requirements for maintaining order often conflict with policies designed to achieve behavioral change and with procedures necessary to protect those within them from arbitrary punishment.

\section{The Relation Between Bargaining and Correctional Goals}

Some bargaining is virtually inevitable between those charged with enforcing institutional regulations and inmates who are supposed to be regulated, for the simple reason that administrators rarely have sufficient resources to gain complete conformity to all the rules. An insufficient number of guards and cells and inadequately threatening punishments create an environment in which institutional rules are often ignored. ${ }^{6}$ At the same time, the attempt to impose order

4. See E. Goffman, On the Characleristics of Tolal Institutions, in Asruums 49 (1951). Goffman applies the term "total institution" to an environment possessing the following characteristics: (1) a single authority with a single organization designed to fulfill official aims; (2) all aspects of life carried on in the same place and in the immediate company of a large group of others, all of whom are treated alike; (3) a high degree of regimentation and scheduling, (4) large blocks of people supervised by a relativcly small staff, with both groups relatively isolated from each other; (5) supervision so integrated that conduct at one place and time may be used by the staff as a comment and check upon conduct elsewhere; and (6) little or no opportunity for privacy, property; or family. Of course, environments may manifest these features to varying degres, from institutions designed to care for the helpless and harmless to less formal structures.

5. For the purposes of the following discussion it will be helpful to focus on those aspects of total institutions which create tensions and antagonisnis among inmates, such as competition for scarce amenities and the frustrations of confinement, and those that create conflicts between inmates and staff, such as "official" goals of discipline and control in contrast to inmate desires to maximize freedom and autonomy. In these areas total institutional environments tend to provoke conflict, yet they contain few if anj; devices to resolve conflict. Institutional roles are strictly defined; few authorities or rules command unanimous legitimacy and respect; important goals on both sides, like preventing or achieving escape, are insusceptible of compromise.

At the same time, other conflict-resolving institutions in our socicty are ill-equipped to mediate conflict within total institutions. First, courts, tribunals, or "citizen panels" are often far from the scene of the conflict. The closed nature of the total institution also makes it difficult to get accurate information, evidence, or witnesses and to follow up any decision with adequate enforcement. Second, the conflicts within the institution are rarely confined to single, well-defined instances but more often reflect ongoing tensions that erupt sporadically and unpredictably. Thus in attenipting 10 derise 3 lasting solution to conflict it may be far more important to focus upon events leading up to or following specific occasions of violence. Third, there is rarely an identifiable "guilty" party clearly in the wrong; a proper resolution would have to take account of a large number of actors, all of whom exist in ongoing, semi-permanent relationships to one another, and all of whom had some part to play in the conflict situation. Therefore instead of a relatively simple judgment in favor of one party and against another, any meaningful solution would have to deal with the tolality of circumstances. In sum, conflict within total institutions creates unique problems of acces, time span, and scope which our normal conflict-resolving institutions are not designed to handic.

6. It might be possible, by extreme measures, to achicie complete conformity cren with very limited staff and resources. See, e.g., B. Betrelueim, TiIE INFonised HeatiT (1961); E. Cohen, Human Behavior in the Concentration Camp (1953); Fischer, Tertor as a System: The Concentration Camp 22 Psycitatric Q. Surrs. 52 (1918). Hovicicr, las: and public outrage greatly circumscribe the methods that can be used to maintain control. 
upon individuals deprived of normal amenities, often lacking opportunities for adequate recreation or privacy, tends to produce violent disorder. ${ }^{7}$ Taken together the scarcity of enforcement resources and the pressures of confinement result in the necessary toleration by correctional administrators and officers of constant violation of institu. tional rules, even if confined to a level considered by administrators to be neither very visible nor very serious. The manner in which this tolerance is allocated among inmates depends fundamentally upon what may be termed "bargains," often tacit and implicit, in which enforcers attempt to gain maximum conformity given their limited resources, and inmates attempt to gain maximum tolerance for their breaches of institutional rules. Recurring contact between guards and inmates creates ample opportunity for an ongoing informal bargaining process. ${ }^{8}$

See, e.g., Landman v. Peyton, 370 F.2d 135 (4th Cir. 1966), cert. denied, 388 U.S. 920 (1967); Holt v. Sarver, 309 F. Supp. 362 (E.D. Ark. 1970). In general, solitary confinement, loss of "good time," or a bad "record" at parole hearings are among the worst punish. ments which a contemporary American correctional institution can invoke.

7. Some disorder will come even from inmates who want to "do their own time" and avoid getting into trouble, because inmates are aware that much rulc-breakingparticularly the minor, low-visibility kind-will get by without any official sanction. Thus, even if they intend to avoid getting involved in the inmate social system, they will still be motivated to seek those small, officially prohibited amenities and freedons which make life somewhat more bearable. See J. IRwin, THE FeLON 70, 71 (1970),

In addition, inmates have an incentive to break minor institutional rules becatise breaking the rules serves a more subtle psychological purpose. Within the total institution and the deprivations associated with it, the attainment of even minor gratifications, taken for granted when the inmate was outside the institution but now prohibited by institutional rules, takes on an importance which transcends their specific valuc to the inmate; the attainment reaffirms the inmate's sense of being an individual, a "man," capable of autonomous action, and able to satisfy his own needs. See E. Goffman, On the Characteristics of Total Institutions, in AsYLums 49 (1961).

8. Enforcement without resort to bargaining-even with limited cnforcenent re sources relative to the amount of violation-is theoretically possible. It implies that the officer enforce the rules so far as possible whenever he confronts violation; and al. though he may confront more violations than he has time or resources to disciplinc, he would merely enforce as much as he could, aiming first at the most inmediate and serious violation. In this connection see Goldstein, Police Discretion Not to Involk the Criminal Process: Low Visibility Decisions in the Administration of Justice, 69 YALE L.J. 543 (1960), who recommends that police officers fully enforce the law, even granted the limitations on personnel, time, and investigative devices, by means of "passive enforcement," i.e., not seeking out offenders for certain classes of crime, but arresting whenever directly confronted with an offense.

But a policy of "passive" full enforcement runs into problems in a total institution like a prison. If there are classes of rules which are being violated by large numbers of inmates at the same time, all at about the same level of intensity and visibility, and all simultaneously obvious to a correctional officer (e.g., violations of rules against talking, possessing contraband cigarettes, decorating the cells, taking bets, or cngaging in homo. sexual activity by mutual consent), the criteria for selecting certain violators over others for punishment cannot be immediacy, seriousness, or actual confrontation. Within a total institution an enforcer is often confronted with a large amount of minor rule. violation, all at about the same level of immediacy and seriotisness. Given limited resources and an incentive not to use force or send in a large number of disciplinary reports (see p. 729 infra), the correctional officer is compelled to establish priorities of enforcement and engage in selective discretion. It is in developing the criteria for stich discretion that bargaining comes about. 
Although some form of bargaining has long been recognized as a basic process of control within prisons and other total institutions, it is not at all clear that a system of control which relies upon private, particularized bargains between staff and inmates contributes to the goals of rehabilitation, order, or protection from arbitrary punishment. In fact, within the day to day bargaining process often the only goal sought to be achieved by the institution is short term surface order-the semblance that everything is running smoothly with no official (or public) cause for alarm.

\section{A. The Myth of Custodial Efficiency}

The official goals of the typical correctional institution often contradict one another. Any attempt to achieve perfectly regimented order inside the institution comes into conflict both with procedures designed to protect inmates from arbitrary punishment and techniques aimed at providing rehabilitation.

The day to day rules which dominate most correctional facilities are, to say the least, not designed primarily to benefit inmates. Although the safety of inmates is an important consideration and many rules contribute to protecting inmates from one another, the vast majority of rules exist to make the custodial job easier. Highly regimented schedules, stringent requirements for neatness and cleanliness, provisions forbidding such "contraband" as personal effects and letters, strictures against giving legal advice to other inmates, and rules which permit talking only at certain times exist to help make the custodial job as automatic and predictable as possible.10 Such

9. See Sykes, The Corruption of Authority and Rehabililation, 34 Soc. Fonces 257 (1956). See also Cloward, Social Control in the Prison, in TuEoneticte Stubies, supra note 3, at 20; Arcleery, The Government Process and Informal Social Control, in Tiue Prison: Studies in Institutional Organization and Cianige 149 (D. Cresscy ed. 1961); Ohlin \& Lawrence, Social Interaction among Clients as a Treatment Problem, 2 Soc. WORK 3 (1959). See generally P. BAChracil \& M. BARATz, Power aNd PoIETT' (1970); P. Blau, Exchange and Power in Social Life (1964).

10. Demands of inmates in pre-riot or post-riot negotiations provide one clue to the kind of rules enforced against them. The demands of the Atica inmates concerned conditions for having visitors, eligibility for work-release, and amenities inside the prison such as a pork-free diet. N.Y. Times, Sept. 14, 1971, at 1, col. 6. Those of the Walpole inmates concerned greater frecdom of morement inside the prison, an cnd to censorship of the prison newspaper, permission to take showers every day, and visiting privileges in rooms. N.Y. Times, Oct. 3, 1971, at 60, col. 1. At Washington State Penitentiary, the demands of the inmates included more variety in prison uniforms, the opportunity to grow beards and sideburns, access to telephones, and more varied work assignments. N.Y. Post, Nov. I, 1971, at 35, col. 1.

Cochran's study of formal disciplinary procedures at Cheshire Reformatory resealed that the largest number of inmate violations reported by guards had little to do with behavior toward other inmates, but concerned talking (tienty per cent of reported violations), disorderly conduct, including "sniffing" (17.7 per cent), and contraband 
sterile order need not, in theory, rely on brute force to maintain itself. The correctional administrator has in his possession an arsenal of more subtle weapons-viz. the capacity to make a whole range of decisions which vitally affect the daily life of the inmate. And as the correctional facility adds new rehabilitative programs and activities, administrative discretion becomes broader and the capacity to gain conformity by way of implicit threats and rewards is that much greater. The administrator can bargain with grades of classification calling for many different degrees of custody; he can offer schooling, jobs, training programs; he can grant furloughs, work-release, school release, weekend release; he has power over assignments and transfers; most importantly, he can recommend parole, he can revoke "good time," and he has command over the "indeterminate sentence."11 All that is demanded of the inmate is cooperation-adherence to the mechanical custodial rules and a willingness to avoid trouble. ${ }^{12}$

found in cells (ten per cent). Cochran, Formal Discipline in Corrections, 1969 (unpub. thesis in Yale Law School Library). See also Jackson v. Godwin, 400 F.2d 529 (jth Cir. 1968) (prison regulations allowed prisoners to receive only home town newspapers); Carey v. Settle, 351 F.2d 483 (8th Cir. 1965) (a prisoner could not complete two cor. respondence courses because he had more than five books in his cell, a condition which officials termed a "fire hazard"); Sostre v. Rockefeller, 312 F. Supp. 863 (S.D.N.Y. 1970), rev'd in part sub nom. Sostre v. McGinnis, $442 \mathrm{~F} .2 \mathrm{~d} 178$ (2d Cir. 1971) (an inmatc had been placed in solitary for the following "infractions" of prison rules: dispensing per. sonal law books to other prisoners, unlawful correspondence, preparation of legal papers for other prisoners, "threats and boasts" that he would escape, and a contraband emury board found in his cell).

An example of rules designed primarily for efficient and mcchanical custody arc the following from BOARD OF Control of StATE InstITUtions, RULE BOOK IOWA State Peniten'tiaky (1961):

Rule 5. At every signal to fall in for marching, take your place in line promptly. March close up and promptly obcy the orders of your officer. March with hands out of pockets and swinging naturally at sides. Smoking or talking is not permitted while in formation.

Rule 33. At the sound of the morning bell, you must rise promptly, wash, dress, clean your cell, make your bed neatly as instructed, and be in readincss to march out. At the signal, open the door, step out, close the same without slamming, form a line as directed, and wait until order to march.

Rule 35. Do not post or hang any articles on the walls of your cell.

Rule 50. Strict silence must be observed in your cell. Laughing, reading or talking in a loud voice, shuffling of feet, drawing bench across cell floor or talking from cell to cell is strictly prohibited.

Rule 44. Strict silence and decorum must be observed during the meal. Talking, laughing, grimacing or gazing about the room is strictly forbidden.

11. See generally Hirschkop \& Millemann, The Unconstitutionality of Prison Life, 55 VA. L. REv. 795, 831 (1969); Millemann, Prison Disciplinary Hearings and Procedural Due Process-The Requirement of a Full Administrative Hearing, 31 MD. L. REv, 27 (1971); Turner, Establishing the Rule of Law in Prisons: $A$ Mantal for Prisoners' Rights Litigation, 23 STAN. L. REv. 473 (1971).

12. Gaining cooperation by way of awards and privileges is not a new idea. Maconochic, an English penologist of the mid-nineteenth century, originated what he called the "mark system," in which a prisoner's relative freedom would depend upon "subsequent conduct and character evinced by him, rather than the original offense." See J. BAkKX, Alexandek MAconocilie of Norfolk Island 69 (1958). See also F. WINES \& C. Dwigilr, Rerokr 'To TIEE New York Legislature CoNcerning Prisons 45 (1867): "Rehabilitation is best achieved by placing the prisoner's fate ... in his own hands, enabling him, through industry and good conduct, to raise himself, step by step, to a position of less restraint." 
Yet there is a certain incompatibility between the use of these methods and what might be considered fair treatment. The "hands off" doctrine, ${ }^{13}$ under which the public and the courts rationalized averting their eyes from what went on inside the correctional facility, is slowly giving way to the realization that prisoners are entitled to such "basic rights" as freedom from arbitrary punishment, ${ }^{1+}$ with the result that some courts have prescribed elaborate procedures to assure a fair hearing for decisions which have a "major impact" upon prisoners' lives. ${ }^{15}$ Some guidelines call for hearings which go beyond a perfunctory two-minute ceremony ${ }^{10}$ and which are conducted by administrative and treatment personnel not parties to the infraction, or by outside overseers; ${ }^{17}$ the inmate must be given notice of the charge $^{18}$ and an opportunity to be heard in his own defense; ${ }^{10}$ and

Most modern correctional facilities, however, work in just the opposite direction, granting inmates all privileges and rewards at the start, and then gradually taking them away for violations.

13. See Note, Beyond the Ken of the Courts: A Critique of Judicial Refusal to Review the Complaints of Convicts, 72 YALE L.J. 506 (1963). For a case subscribing to this doctrine, see, e.g., Roberts v. Pigelow, 313 F.2d 548,550 (fth Cir. 1963) (prison officials should have "largely unfettered discretion in deciding what security measures are appropriate, and with respect to each prisoner, what relative freedom he safely may be allowed").

14. See, e.g., Sostre v. Rockefeller, 312 F. Supp. 863, 870 (S.D.N.Y. 1970), rev'd in part sub nom. Sostre v. McGinnis, 442 F.2d 178 (2d Cir. 1971):

It is not a function of our prison system to make prisoners conform in their political thought and belief to ideas acceptable to their jailers. On the other hand, one function is to try to rehabilitate the lawbreaker by convincing him of the validity of our legal system. There is little chance that such an objective will be achieved if prisoners are entrusted to those who likewise break the law by denying prisoners their basic constitutional rights.

15. See, e.g., Sostre v. McGinnis, 442 F.2d 178 (2d Cir. 1971); Nolan v. Scafati, 430 F.2d 548 (lst Cir. 1970); Clutchette v. Procunier, 328 F. Supp. 767 (N.D. Cal. 1971); of. Jones v. Robinson, 440 F.2d 249 (D.C. Cir. 1971). See also I'REsident's Cosm's on LAW ENFORCEMENT AND THE AdMinistration of Justice, TASK Force: THE PRISONS 85 (1967). 16. Cochran, supra note 10 , reports that the average time given to a disciplinary: hearing was less than three minutes. In Kritisky v. McGinnis, 313 F. Supp. 1247, 1250 (N.D.N.Y. 1970), it was determined that a disciplinary hearing (1) must be given at a "meaningful time" (2) in a "meaningful manner" (3) with the decision stating the reasons for the determination and (4) indicating the evidence relied upon. See also clutchette $v$. Procunier, 328 F. Supp. 767 (N.D. Cal. 1971); Sostre v. Rockcfeller, 312 F. Supp. 863 (S.D.N.Y. 1970), rev'd in part sub nom. Sostre v. McGinnis 442 F.2d 178 (2d Cir. 1971): Morris v. Travisono, 310 F. Supp. 857 (D.R.I. 1970); Rodriguez v. AlcGinnis, 307 F. Supp. 627 (N.D.N.Y. 1969).

17. See Bundy v. Cannon, 328 F. Supp. 165,172 (D. MId. 1971) (the requirement of an objective and impartial hearing, a basic component of procedural faimess, is violated when the same prison official assumes the dual responsibility of initiating and pressing charges and subsequently determining guilt and assessing the appropriate punishment);
Clutchette v. Procunier, 328 F. Supp. 767,784 (N.D. Cal. 1971) (decisions must be made by a fact-finder not involved in the alleged incident). See also MIODEL PENAL CODE $\$ 304.7$ (Proposed Official Draft 1962), recommending that the disciplinary committec include

a member of the treatment staff, custodial staff, and an institutional physician.

18. See Sostre v. McGinnis, 442 F2d 178 (2d Cir. 1971); Clutchette v. Procunier, 328 F. Supp. 767 (N.D. Cal. 1971); Carothers v. Follette, 314 F. Supp. 1014 (S.D.N.Y. 1970); Nolan v. Scafati, 306 F. Supp. I (D. Mlass. 1969); cf. Jones v. Robinson, 440 F.2d 249 (D.C. Cir. 1971).

19. See, e.g., Bundy v. Cannon, 328 F. Supp. 165 (D.Afd. 1971). See also Awenals Correctional Association, Manual of Correctional Staxdardos 109 (1969). 
the decision must be based upon "substantial" evidence." In addi. tion, some courts have gone further than this inquisitorial model and required, for the administration of "serious" penalties, that the hearing become genuinely adversarial: that the inmate be provided with counsel, ${ }^{21}$ that he be informed of the evidence against him, ${ }^{\text {as }}$ and that he be permitted to present his own evidence and cross-examine the correctional officer bringing charges. ${ }^{23}$ Moreover, rules which were so vague as to forbid "disorderly conduct"24 are now, because of pressure from the courts, ${ }^{25}$ in the process of being transformed into clear, detailed, and specific regulations which give the inmate precise notice of what is to be expected of him and of the possible punishments for infractions.

In short, the "hands off" policy is increasingly being replaced by careful scrutiny over the procedures by which correctional decisions are made. Although courts have been more reluctant to delve into the wisdom of particular decisions or specific rules, ${ }^{20}$ formalization

20. See Bundy v. Cannon, 328 F. Supp. 165 (D.Md. 1971); Clutchettc v. Proculicr, 328 F. Supp. 767, 784 (N.D. Cal. 1971).

21. See Clutchette v. Procunier, 328 F. Supp. 767, 783 (N.D. Cal, 1971) (the inmatc must be given an "adequate counsel-substitute"); Morris v. Travisono, 310 F. Supp. 857, 872 (D.R.I. 1970) (a trained member of the correctional staff must represent inmates in disciplinary hearings).

22. See Bundy v. Eannon, 328 F. Supp. 165, 172 (D.Md. 1971); Clutchette v. Procunier, 328 F. Supp. 767, 782 (N.D. Cal. 1971).

23. See Bundy v. Cannon, 328 F. Supp. 165, 176 (D.Md. 1971); Clutchette v. Procunicr, 328 F. Supp. 767, 782 (N.D. Cal. 1971). Contra, Sostre v. McGinnis, 442 F.2d 178, 187, 198 (2d Cir. 1971). See also p. TAppan, Crime, Justice, and Conkecrion 701 (1960).

The adversarial model in disciplinary hearings has, not surprisingly, met with a great deal of opposition from correctional authorities. Administrators are loath to contradict reporting officers because the officers' authority is often at stake. It is also argued that an adversarial model makes security and custody more difficult because inmates and guards actively recruit witnesses and evidence against each other, thus exaccrbating tensions that already exist within the institution. See Nolan v. Scafati, 306 F. Supp. 1, 4 (D. Mass. 1969).

24. Cochran, supra note 10, quotes one training officer: "We could do away with all the other charges and just have disorderly conduct." See, e.g., MIAine State l'kison, INFORMATION, RULES, AND REgULATIONS FOR INMATES 42, 43 (undated): An inmate is liable for "conduct . . . such as would discredit this institution." STATE DEi'T OF Conk., Tennessee State Penitentiaky Guidance Manual For Prisoners 7 (undated): Disciplinary action may be taken against an inmate for "any conduct not conducive toward re. habilitation or betterment of an inmate"; TEXAS DElARTMENT OF CoRRECTION, RULES AND Reculations 10 (1968): Laziness is punishable; this includes "refusing or failing to do work assigned and refusing or failing to obey orders and instructions."

25. On October 19, 1970, in response to Sostre v. Rockefeller, 312 F. Supp. 863 (S.D.N.Y. 1970), rev'd in part sub nom. Sostre v. McGinnis, 442 F.2d 178 (2d Cir. 1971), the New York Department of Corrections issued new rules concerning cells, use of showers, exercise, visitation, correspondence, and other areas previously left to the dis. cretion of correctional officers. NEW YORK DEPARTMIENT OF CORRECrions, REgulations For SPECIAL Housing Units pt. 301 (1970).

26. Although courts have not as yet substituted their own rules for already existing rules governing prisons, several courts have ordered administrators to devise new rules and have supervised negotiations between administrators and inmates over the drafting of the new rules. In Morris v. Travisono, $310 \mathrm{~F}$. Supp. 857, 859 (D.R.I. 1970), Judge Pettine oversaw negotiations between prisoners and prison officials and ordercd that the 
of the decision-making procedures alone has severely curtailed administrative discretion. Moreover, formal rules and formal hearings approaching the adversary model enable inmates to pit their own resources against correctional staff in ways that challenge institutional solidarity and encourage confrontations in other areas. Finally, hearings and other formal procedures take time and resources away from maintaining efficient custody. Mechanical and efficient custody is thus compromised, perhaps irreparably, by strategies for legal pro. tection.

Though the courts pull in one direction, penologists, psychologists, and sociologists push the correctional administrator in another. Their emphasis is upon treatment, and their focus is the individual offender and his particular needs. ${ }^{27}$ As custodial procedures aim at gaining unquestioning conformity, rehabilitation aims at giving the inmate a sense of responsibility. While mechanical and efficient custody imposes schedules and takes initiative away from the inmate, treatment personnel argue for permitting the inmate to organize his own time and his own activities. ${ }^{28}$ By providing areas of choice, treatment aims at making the inmate a more responsible and independent individual..0

The outcome of the compromises among legal protection, rehabilitation, and custodial efficiency is often a generalized and vague ad-

results of the negotiations be printed and distributed to the prisoners for their final approval. After receiving responses from the inmates to the proposed regulations, the court then implemented the rules by an interim decree, id. at 862 , but retained jurisdiction for eighteen months to allow for necessary changes and to make sure that the new rules were implemented. In Sostre, Judge Motlcy gave prison officials three months in which to submit new proposed regulations for court approval and inmates one month following to file objections to the rules. 312 F. Supp. 863,889 (S.D.X.Y. 1970), rev'd in part sub nom. Sostre v. IfcGinnis 442 F.2d 178 (2d Cir. $197 \mathrm{I}$ ). For a general discussion of the limits and reactions to judicial interventions in correctional management. see Kimball \& Newman, Judicial Interuention in Correclional Decisions: Threat and Response, 14 CRIME \& Delinguescy 5 (1968).

27. See generally Fox, The Effect of Counseling on Adjustment in Prison, 32 Sac. ForCes 285 (1954); Frank, The Dynamics of the Psychotherapeutic Relationship, in Mles: tal Illness and Social Process (Scheff ed. 1967); Miller, The Prison Code, 114 As. J. PSYchiatRy 583 (1958).

28. During recent years a small library of literature has grown up around the theme of conflict between custody and treatment objectives in correction. Sce, e.g., Cresey; Contradictory Directives in Complex Organizations: The Case of the Prison, 4 AD. Sci. Q. 1 (1959); Cressey, Limitations on Organization of Treatment in the Modern Prison, in in THE PRISON 107 (D. Cressey ed. 1961); Ohlin, Conflicting Interests in Correctional Objectives, in Theoretical Studies, supra note 3, at 111; Piliavin, The Reduction of Custodian-Professional Conflict in Correctional Institutions, 12 CRINe \& Deusiouevicr 125 (1966); Powelson \& Bendix, Psychiatry in Prisons, lf Psychitri 73 (1951); Whecler, Role Conflict in Correctional Communities, in TuE Prisox 229 (D. Cresscy cd. 1961); Zald, Power Balance and Staff Conflict in Correctional Institutions, 6 AD. ScI. Q. 22 (1962).

29. For a fascinating analysis of the importance of giving inmates a sense of responsibility, independence, and capability, sec R. Rubessteis \& H. LAsswels, TuE Sharing of Power in a Psychiatric Hosmital (1960). 
ministrative policy that contains elements of all three goals, depend. ing upon the relative impact of the courts, treatment personnel, and custodial personnel. As administrative policy becomes less decisive, the guard or correctional officer at the bottom of the hierarchy, who comes in direct contact with the inmate, conforms to his most specific understanding of what that policy is; as the administrative policy becomes vaguer and less coherent, the policies of the low-level correctional officer have greater impact. ${ }^{30}$

\section{B. Surface Order as an Operating Goal}

The lowest-rung correctional officer typically takes as his goal what might be called the maintenance of "surface order." ${ }^{31}$ Surface order means that inmates are conforming voluntarily to the institution's most important rules, and custody is running smoothly; it is required only that there be no visible trouble and no cause for alarm. In other words, so long as surface order is maintained no force need be used, no punishment invoked, no administrative time and resources expended in trial procedures, and no concern aroused in the public. It is thus a different goal entirely from that of mechanical and efficient custody, which demands clockwork regimentation and spotless cells, because surface order allows a degree of non-conformity under the surface-a degree of tolerance by the correctional officer of lowvisibility violations.

Surface order is the correctional officer's most specific understanding of policy, since it is the criterion by which his performance is judged. ${ }^{32} \mathrm{He}$ is rated by his ability to maintain control without force,

30. See Lovell \& Nelson, Correctional Management and the Changing Goals of Cor. rection, in Problems in Criminal Justice Administration 82 (M. Cohn cd. 1969), who citc a nationwide survey and study of correctional administrators, which included intervicws, time and motion studies, and questionnaires. The study concludes that "administrators, finding it difficult to harmonize treatment and custody goals, have tended to generalize policy to such an extent that subordinate staff are relatively frec to decide many significant questions of action and procedure." Id. at 87-88.

31. This term is used in the same sense as the expression "surface placidity" is cmployed by Rutherford, Formal Bargaining in the Prison: In Search of a New Organiza. tion Model, 2 Yale Rev. L. \& Soc. Ac. 5, 7 (1971).

32. See Sykes, The Corruption of Authority and Rehabilitation, 34 Soc. Fonces 237, 239 (1956): "A troublesome and noisy cellblock reflects upon the guard's ability to handle prisoners-an important basis of merit rating for pay increases and promotions." See also Schrag, Some Foundations for a Theory of Correction, in THE PusON 309, 340 (D. Cressey ed. 1961): "The continued employment of given officers depends largely on the degree of voluntary cooperation such an officer can win from the inmates." Goffunan documents a similar process within a mental institution: staff who are engaged in certain maintenance activities would have to give out "patronage" to certain inmates who workcl with them, lest the staff member be forced to report at the end of the year a declining 
to gain voluntary cooperation. No other correctional goal falls so clearly or so specifically upon his shoulders. Rehabilitation can only be tested at some undefined point in the future, and is an aim for which the correctional officer cannot be held solely accountable. Legal protection is a goal which cannot be quantified and in which the correctional officer has but a limited role to play. Mechanical and efficient custody is an ideal which the administration has neither the time nor the resources to insist upon. But the degree of obvious disorder and gross deviance under the correctional officer's immediate charge can be judged and measured here and now and reflects most directly upon his performance. The force needed to control deviance, the time and resources required before a punishment may be inflicted for it, and public inquiries and pressures concerning any disturbance are all specific costs which can be measured and understood with far greater clarity than the nonachievement of any other goal.

Surface order is essentially achieved and maintained through what may be viewed as a bargain between the correctional officer and the inmates. In return for the toleration of a degree of low-visibility violation under the "surface," the inmates agree to avoid larger and more visible violations which would necessitate the use of force. ${ }^{33}$ The bargain may be as casual as a mere tacit understanding that "you play ball with me, and I'll play ball with you," or it may be highly structured and selective. Whatever its character, correctional officers and inmates become mutually dependent. The inmates maintain surface order for the correctional officer and the correctional officer turns his back on minor violations. ${ }^{34}$

number of patients engaged in his activity. E. Goffman, The Underlife of a Public Institution, in AsYLUMs 171, 287 (1961).

Interviews with correctional officers confirmed the phenomenon. Correctional officers admitted that they were officially discouraged from submitting disciplinary reports, that the submission of many reports would be an indication to the administration that the officer was not doing his job properly, and that 200 many such reports would mean dismissal. Interviews with correctional officers, Somers State Prison, Somers, Connecticut, March 1971.

33. The experienced correctional officer wants to avoid the use of force for a number of reasons. Not only does the use of force cast doubt on his ability to "handle" inmates in the minds of his superiors, but it may also cause doubts in the minds of those whom he is trying to control. The actual application of force may stiffen resistance and make it more difficult to keep order in the future and may also teach those subject to the enforcement that the punishment is not so bad as they might have anticipated. See generally P. Bachrach \& M. BARATz, Power and Poverty (1970); 1'. BLAU, ExcilaNGe AND POWER IN Social LIFE (1964).

34. The inmate-staff bargain has been exhaustively described and documented. Sce, e.g., Cloward, Social Control in the Prison, in THeoneticat. Studies, supra note 3. at 20; McCleery, The Governmental Process and Informal Social Control, in Tite l'usox (D. Cressey ed. 1961); Sykes, The Corruption of Authorily and Rehabilitalion, 31 Soc. Forces 257 (1956). 
The amount of "under the surface" violation bargained away by the correctional officer will be related to both real and perceived power relationships. The correctional officer knows that his enforcement resources, including other guards and threats of punishment, are inadequate to achieve mechanical conformity to all institutional rules. He also knows that inmates have the capacity, singly or in groups, to create major disturbances, threatening his job or even his life. Further, he understands implicitly that the hierarchy of correctional administrators, public officials, and the public at large to whom he must answer is progressively indifferent to what goes on inside the institution so long as a modicum of order is maintained without riots or escapes. In a real sense, the correctional officer's crude calculation of the amount of rule violation to be allowed is related to the balance of power between the institution and its in. mates, with the power of the institution constrained by the public's desire to minimize the dollar cost of adequate public security.

The amount of under the surface violation which will be tolerated or bargained away by the institution can usefully be seen as a function of the inmates' capacity to "charge" the institution and the public-at-large far too much for complete enforcement of efficient and orderly custody relative to the willingness of the public to pay. This is a highly abstract and imprecise formulation, but it provides the outline of a relationship: as a general rule, the public-at-large, as represented by the political process, will provide the minimum amount of enforcement resources necessary to satisfy its demands for security (as well as the treatment of offenders). Any other policy would seem an irrational allocation of resources. Similarly, the inmate seeks to minimize the sum of the cost of conformity to institutional rules and the cost/risk of punishment. These two "rational" calculations are the basis of bargaining between institution and inmate and form the simplest recognition of mutual poiver. The inmate recognizes the enforcers' ability to "charge" him more than he is willing to "pay" after a point, and the institutional enforcer recognizes the inmate's ability to do the same. ${ }^{35}$

35. The idea outlined in the text may be elaborated as follows: In order to reduce the total cost of crime plus the cost of enforcement to its lowest point, every increase in the cost of enforcement and prevention must bring about a greater decrease in the cost of crime. For any particular class of crimes, the ideal enforcement policy would be extended to the margin where the decrease in the cost of crime is cqual in value to the cost of enforcement and prevention. For correctional institutions, this "rational" policy would dictate that the public spend no more on locking away its criminals than the 


\section{The Structure of Private Bargaining}

It is in the expression of this power relationship that bargaining can either support the goals of rehabilitation and protection from arbitrary punishment or undermine them completely. The difference depends upon whether the bargaining is carried on privately, between correctional officers and inmate "leaders," or openly, between administrators and the entire inmate population. From the point of view of each actor within the correctional institution, private bargaining between correctional officers and select inmates is perhaps

marginal advantage it receives in getting its criminals off the streets and out of its collective mind, while subscribing to minimum standards for confining prisoners. Similarly, the inmate's most "rational" policy for violating the rules would be to enlarge his rule-violating activity to the margin where an additional benefit of violation results in an equal or greater increase in the risk and harm of punishment.

of course, included in the "cost of enforcement" side will be long-term costs, such as the cost of continued imprisonment and rehabilitation programs and the effectiveness of different policies upon the future cost of criminal activity and prevention; included on the "cost of crime" side-beyond its dollar cost-will be more general social costs such as insecurity, fear, worry, and unpleasantness which such criminal activity causes to the public-at-large. In assessing the costs of punishment for inmates, one must consider the very limited impact which the threat of institutional punishment can have on those already being deprived of a great many amenitics.

For a more rigorous and more general formulation, sec Becker, Crime and Punishment: An Economic Approach, $76 \mathrm{~J}$. PoL. Econ. 169 (1968) and Rottenberg \& Landes, Round Table Allocation of Resources in Law Enforcement, 59 AM. EcoN. KEv. 504 (1969).

One might apply this analysis more generally to the bargaining that occurs between those who try to enforce the law and those who deviate from the law, particularly within inner-city communities. It is common knowledge that enforcement resources are inadequate to maintain strict adherence to law within these communities, and the transactions which result bear marked resemblance to transactions within correctional institutions. Two common examples of transactions designed to reduce the "costs" to enforcers and deviants are what may be termed the "prosecution" bargain and the "plea" bargain.

The "prosecution" bargain calls for agreement on the part of the desiant (or inmate) to endure a slightly higher cost of conformity to official rules or laws by parily altering his behavior, in return for an even greater decrease in the cost and risk of punishment. because the enforcer agrees not to arrest and prosecutc. Although the coforeer spends slightly greater enforcement resources in supervising, checking, and overseeing, he gains far greater savings in reducing the cost of crime. The prosecution bargain is most common to administrative enforcement but is also relevant to criminal enforcement. To take a specific example, late in 1966 Chicago's Black Stone Rangers entered into a formal bargain with the Chicago police whereby in return for surrendering their weapons and not fighting other gangs the Rangers got the police to agree to drop charges against their leaders and to disarm a rival gang. See Horowitz \& Licbowitx. Sacial Deviance and Political Marginality: Touard a Redefinition of the Relationship Betuecn Sociology and Politics, 15 Soc. Pronlems 291 (1968). See also Goldstein, Police Discretion Niot to Invoke the Criminal Process: Low I'isibility Decisions in the Administration of Justice, 69 YALE L.J. 543 (1960).

The "plea" bargain is a second common transaction, involving an estimated ninetythree per cent of criminal convictions. Here the deviant gives up a full trial but in so doing significantly reduces the cost and risk of punishment; the enforcer-already strained for resources-avoids the costs and time of a full trial. Both secm to be "better off" than they would be had no such transaction occurred. See Note, The Unconstitu. tionality of Plea Bargaining, 83 HARv. L. REv. 1387 (1970). Sec also Newman, Pleading Guilty for Consideration: A Study of Bargained Justice, 46 J. CRIM. L.C. \& P.S. 780j (1956): Vetri, Guilty Plea-Bargaining: Compromises by Prosecutors to Secure Guilty Pleas, 112 U. PA. L. REv. 865 (1965); Comment, The Influence of Defendant's Plca on Judicial Determination of Sentence, 66 YALE L.J. 204 (1956). 
the most natural response to the realities of inmate power. But viewed from a larger perspective, in terms of the goals of the institution and the real needs of those incarcerated within it, private bargaining is dysfunctional.

\section{A. The Distribution of Custodial Largesse}

The willingness of the correctional officer to tolerate under the surface violations amounts to a kind of custodial "largesse" which can be distributed in a highly particular manner to selected inmates. In fact, by distributing it unequally, that is, by offering higher degrees of immunity to select inmates, the correctional officer can maximize the resultant degree of surface order. ${ }^{30}$ Custodial largesse is allocated most generoisly to those inmates who exert control over other inmates. In return for private rewards of enforcement discretion, these "leader" inmates exercise a moderating influence over others, enabling the correctional officer to maintain surface order much more effectively. ${ }^{37}$ Leadership among inmates in turn relies upon the solidity of the inmate society for its effectiveness ${ }^{38}$ and

36. Framed more generally, the use of discretion and selective enforcement permits greater offers to be made to certain deviants than could be made to the gencral community of deviants, in return for net savings to the enforcers. For example, greater thail normal plea bargains may be offered those deviants who would otherwise have the resources to mount elaborate and cxpensive trials; enforcers thercby score a net saving, as do the selected deviants. In a similar way, greater than normal prosecution bargains might be offered those deviants whose deviant activity, once altered, significantly reduces the total cost of crime; enforcers thereby lower their net costs, as do the selected deviants. High "surveillance" bargains, providing immunity from enforcement and surveillance, might be offered those deviants who supply information about other deviants which enables enforcement to be conducted much more efficiently. Again, cuforcers gain a net reduction in costs, as do the selected deviants. Or finally, higher than normal bargains may be offered those deviants who are able to exert control over other deviants, and thereby reduce the total cost of crime beyond the cost to the enforcers of the particular bargain. In all these cases enforcers gain maximum advantage of their limitcd enforcement resources by offering their discretion selectively in private bargains. With only a limited amount of discretion to be bargained in the first place, the selected deviants benefit at the expense of the non-select, who end up bearing a greater shitre of the actual enforcement burden than they would had no private bargains bcen struck.

37. In effect, leader inmates carry on enforcement sub rosa. Any overt delegation of enforcement to leader inmates would in all likelihood be found to be illegal. See, c.b's Holt v. Sarver, 309 F. Supp. 362 (E.D. Ark. 1970), which prohibited the use of prisoner trustees in the control of other prisoners because, among other reasons, of the degrec of uncontrolled violence and brutality created by such a system.

38. Extensive literature has grown up around the theme of solidity of the "Inmatc society." See, e.g., D. Clemmer, The Prison Community (1958); Atchley \& MicCase, Socialization in Correctional Communities; a Replication, 33 AM. Soc. REv. 774 (1968); Berk, Organizational Goals and Inmate Organization, 71 AM. J. Soc. 522 (1966); Densin, Collective Behavior in Total Institutions: The Case of the Mental Hospital and the Prison, 15 Soc. Pronlems 353 (1968); Garabedian, Social Roles and Processe's of Sociali. zation in the Prison Community, 11 Soc. Problems 139 (1963); Grosscr, The Rolc of Informal Inmate Groups in Change of Values, in Prison WrTHIN Sociery 298 (L. Hazcl. rigg ed. 1968); Schrag, Social Role, Social Position, and Prison Social Structure, 1959 PROc. OF THE AM. CORR. Ass'N 178; Street, The Inmate Group in Custodial and 'Trealment 
usually devolves upon the criminally "mature," i.e., those who already know the tacit rules and have developed some familiarity with the correctional officers. ${ }^{30}$

The relationship between leadership inmates, the inmate socicty, and the correctional officer is thus symbiotic and interdependent. Although the solidity of the inmate society is often the product of a collective response to correctional officers and the deprivations of custody, more efficient control within the inmate society actually results in more efficient custody. ${ }^{\text {to }}$ While correctional officers bestow custodial largesse upon inmate leaders, the lenders obtain and keep their position partly because they maintain good relationships with correctional officers and so gain access to information, goods, and immunities which other inmates lack. ${ }^{41}$ The leader inmate becomes

Settings, 30 AM. Soc. REv. 40 (1965); Sykes \& Messinger, The Immale Social System, in THEORETICAL STudies, supra note 3, at 5; Wellford, Faclors Associated wilh Adoption of the Inmate Code: A Study of Normative Socialization, 58 J. Cris. L.C. \& PS. 197 (1967); Wheeler, Socialization in Correctional Communities, in Prusox Wrrums Socien 150 (L. Hazelrigg ed. 1968).

The inmate "code" has been explained in a raricty of ways-as a "response to the deprivations of prison life" by G. Sykes, THE Society of Cirrives (1958); as the result of anomie, by Cloward, Social Control in the Prison, in Turonericst. Strutes, supra note 3, at 20; as a way of "reducing and channeling aggression," by Crosser, External Setting and Internal Relations of the Prison, in TuEORETICAL STUdies, supra note 3, at 130; and as a means of "maintaining self-identity," by McCorkle \& Korn, Resocialization Within the Walls, in Sociology of Punisiment and Correction 409 (N. Jolinston, $L$. Savitz \& M. Wolfgang eds. 1970).

39. See Clemmer, Leadership Phenomenon in the Prison Community, 28 J. Ass. Isst. Crim. L. \& Criminology 861 (1938); Schrag, Leadership Among Prison Immales, 19 AM. Soc. REv. 37 (1954). See also Farquier \&. Gilchrist, Some Aspect of Leadership in an Institution, 13 CHIL Develomsent 55 (1942); Grusky, Organizational Coals and the Behavior of Informal Leaders, 67 AM. J. Soc. 59 (1959).

40. The paradox is developed at some length by Betrelineis, supra note 6 , at 162: "The prisoners make efforts to defend themselves through prisoner organizations . . . with the resulting contradiction-the more effective the organization, the better it served the SS." The prisoner hierarchy and organization in camps cnabled the SS to control tens of thousands of prisoners with only a handful of men, id. at 104. MlcCleery: supra note 34 , at 162 , describes the process in an American prison: "No amount of naked force can substitute for peer-group enforcement of norms, which features social disapproval and physical harassment." BLAU, supra note 9, at 200, articulates the more general case: "The distinctive feature of authority is that social norms accepted and enforced by the collectivity of subordimates constrain its individual members to comply with directives of a superior. Compliance is voluntary for the collectivity. but social constraints make it compelling for the individual. . . The pressure to follow suggestions and orders does not come from the superior who gives them but from the collectivity of subordinates." All this would suggest that the powcrful inmate socicty has a great deal of-potential for changing behavior patterns inside the correctional institution for ill or good.

41. Cloward details the "illegitimate opportunity structures" which tend to make the upwardly mobile leadership inmate more conservative. The leader inmate gains access to illegitimate goods and services and thereby occupies a "merchant" or "peduler" leadership role, he gains access to information and becomes the "politician," or he acquires status and-gains the "right guy" leadership rolc. In cach case, his opportunity depends upon maintaining a monopoly of access to the illicit property, and thereby keeping the property illicit. The leader inmate thus obtains a vested interest in limiting and curtailing access of other inmates to the same "illegitimate" opportunities. He has an interest in maintaining the rules and regulations and broad enforcement which 
the broker in the bargain, the sole channel through which custodial largesse is distributed. As broker, his "profit" depends upon maintaining his monopoly. He must therefore satisfy both sides of the bargain-maintaining adequate control over the inmate society while at the same time distributing custodial largesse so that his power is maintained. Thus the entire set of bargaining relationships reflects the correctional institution's coming to terms with the reality of inmate power, but in a highly particularized manner. Custodial "largesse" is distributed to particular inmates according to their ability to control others, and these others are "bought off" in turn, depending on their own capacities to cause or control visible violence.

Just as leader inmates may earn the full measure of enforcement discretion, certain "marked men" may find even the normal amount of official tolerance wholly or partially withdrawn. The inmate who causes some major violation may lose his immunity for small violations. He is labeled a "troublemaker" in the eyes of the officers, and the formal hearing officially recognizes him as such in the eyes of the correctional administrators. From then on, reported violations by this troublemaker do not reflect upon the ability of the officer to gain conformity because the troublemaker is obviously a special case, more difficult to handle than the average inmate. The troublemaker thereby becomes liable for every small infraction he commits. $\mathrm{He}$ is cast out of the bargain and only gradually gets back in. ${ }^{42}$ Again, the process is often informal and unstated. After his major violation the inmate quite naturally gets closer supervision, and minor violations are bound to be more readily observed. This is the case whether or not he is judged "guilty" at the formal hearing; he is still a "marked" man to correctional officers. ${ }^{43}$ In this way informal guilt has little to

creates his monopoly condition. This is the classic "crime tariff" situation. Cloward, Social Control in the Prison, in Theoretical Studies, supra note 3, at 20. See also the description of "patronage" in a mental hospital in $\mathrm{E}$. Goffman, The Underlife of a Public Institution: A Study of Ways of Making Out in a Mental Hospilal, in Asyuums 290 (1961).

42. See McCleery, The Governmental Process and Informal Social Control, in Tut: Prison 149 (D. Cressey ed. 1961).

43. See, e.g., G. Jackson, Soledad Brother 69, 213 (1970) (prison letter of Nov, 13, 1965): "I will relish the transfer part. All of the officers here have preconceived notions about my patterns of behavior now. Consequently, it is somewhat hard for me to avoid falling under suspicion for almost every misdeed perpetrated by a black"; (letter of May 8, 1970): "I get accused of everything that cannot be positively established clsewhere...."

Another arrangement is described by Berreluem, supra note 6 , at 126 . During the hearings before punishment was to be inflicted at Dachau, the accused was told of the charge and given a chance to refute it, but "if he knew what was good for him he made no effort to defend himself" because, even if acquitted, the guard would make life impossible for him. 
do with official or formal guilt; informal guilt summons the high penalty of full enforcement and betokens the disappearance of that measure of tolerance enjoyed by other inmates. In addition, the troublemaker becomes a convenient scapegoat for other large violations where the identity of the violator is difficult or impossible to determine and which would otherwise reflect upon the correctional officer's ability to handle inmates. ${ }^{\text {H4 }}$

\section{B. Private Bargaining and Correctional Goals}

The interesting and important question is the effect of these private bargaining relationships on the goals of rehabilitation, protection from arbitrary punishment, and institutional order. The answer is that all three goals are compromised.

Rehabilitation programs are designed inter alia to remove the inmate from his position of powerlessness and vulnerability within the inmate society (and within society at large) and to provide him with new models, thus encouraging dignity, self-respect, and personal responsibility. ${ }^{45}$ Treatment often depends upon the development of trusting, frank relationships between the inmate and the treatment staff. ${ }^{46}$ But private bargaining tends in the opposite direction. Bargaining over custodial largesse reinforces a sense of powerlessness for most inmates, ${ }^{47}$ since they depend upon leader inmates to gain advantages or avoid violence. 48 The process of carrying on "illicit" activities forbidden by prison regulations also serves to reaffirm the inmates' own deviant self-image; their goals and methods are as illegitimate as they were outside the prison walls, and they still think of them-

44. In a similar way, law enforcement personnel urge defendants to accept responsibility for many unsolved crimes in return for a lower sentence. Enforeers thereby purport to solve many crimes and so create the appearance that they are doing their job successfully. See J. Skolvick, Justice Without TrLal $16 \pm$ (1960).

45. See generally D. STREeT, R. VINTER \& C. Perrow, Organization for Theatmest (1966); E. STUdT, S. Messinger \& T. Wilson, C-Unit: SeArcil for Comaunity in Prasos (1968) [hereinafter cited as C-UNIr]; Garrity, The Prison as a Rehabilitation Agency, in The Prison 358 (D. Cressey ed. 1961); Powelson \& Bendix, Psychialyy in Prisons, 14 Psychiatry 79 (1951); cf. R. Rubenstein \& H. Lasswell, Tie Silarinc of Power in a Psychiatric Hospital (1966).

46. See Frank, The Dynamics of the Psychotherapeutic Relationship, in MENTAL ILlness and Sociai, Processes (T. Scheff ed. 1967).

47. See G. SYkes, THe Society OF CArTives 73,75 (1958).

48. See, e.g., Cressey \& Irwin, Thieves, Convicts, and the Immate Culture, 10 Soc. Problems 142 (1962); McCleery. Communication Patterms as Bases for Systemis of Au. thority and Power, in THEORETICAL Stubies, supra note 3, at 49 ; Ohlin \& Lawrence, Social Interaction Among Clients as a Treatment Problem, 1 Soc. Work 3 (1959); Rabow \& Elias, Organizational Boundaries, Immate Roles, and Rehabilitation, 6 Crisse \& DE. Linouency 8 (1969); Schrag, Social Role, Social Position and Prison Social Structure, 19j9 Proc. of THE AM. Corr. Ass'N 178; Wilson \& Snodgrass, The Prison Code in a Therapeutic Community, 60 J. CrIs. L.C. \& P.S. 472 (1969). 
selves as violators of social norms. ${ }^{40}$ The bargaining itself proceeds in an atmosphere of mistrust and suspicion-lines of communication are selfishly guarded by leader inmates, correctional officers refuse to acknowledge the fact that violations are occurring, and the maintenance of surface order requires low visibility, collusion, and relitive secrecy. Most importantly, and most damaging to the goal of rehabilitation, inmates are taught that what is most rewarded is physical strength, intimidation, and exploitation..$^{50}$

Private bargaining may also undermine institutional procedures aimed at protecting inmates from arbitrary punishment. The mech. anisms of legal protection are designed to insure that punishment is administered equally for infractions that are in fact ascribable to the individual accused of committing them. But "punishment" most often refers to formal correctional decisions resulting in solitary confinement or changes in parole eligibility. Within the context of institutional rules that deny the inmate all sorts of day-to-day amenities, however, the most significant form of punishment is the discriminatory enforcement of prison rules among inmates. The decisions by correctional officers to grant soft, selective enforcement to certain inmates and the manner in which those inmates distribute this custodial largesse determine the real relative degree of punishment. The formal hearing to determine factual "guilt" is, in an important sense, a sideshow unrelated to the real adjudication. Whether the infraction did or did not occur as a result of an inmate's action is not the issue; the inmate wants to avoid the formal hearing because a determination of either guilt or innocence in the formal sense may result in full en. forcement of rules against the alleged violator in the future. In addition, the chances are that he is formally guilty anyway, as is almost everyone else. The private bargains between correctional administrator and correctional officer, between correctional officers and leader inmates, and between inmate leaders and other inmates determine the real allocation of punishment within the correctional facility. In the end, it is those inmates who are the weakest, the most unpopular,

49. See generally E. Lemert, Human Deviance, Social. I'roulems, and Social Cone TROL (1967), for the suggestion that the "secondary effects" of rulc-breaking-the processes which label a person as deviant and alter his self-image from a normal member of society to that of an "outcast"-can have far greater impact on postponing rehabilitation and continuing criminal activity than a specific penalty.

50. Bargains which are limited to select inmates on the basis of their ability to control others provide the inmate society with models of "stuccess" in an cuvironment otherwise dominated by failure. But often the most "successful" leaders achicve their" status by methods which, if emulated outside the prison walls, would lead only to mote crime and further imprisonment. 
the most inexperienced, or the members of a racial or ethnic minority who bear the full brunt of actual day-to-day punishment. ${ }^{51}$

Finally, the maintenance of any real institutional order, including the safety of inmates, is made more difficult by private bargaining. First, so long as low-visibility violations are officially tolerated, the correctional officer might be tempted to take personal advantage of his own monopoly of access to certain tolerated but illicit activities. Since bargains are made privately, no check exists upon possible pay-

51. An analogy may be made betwecn private bargaining within the prison and law-enforcement bargains outside it. The latter often lack any specific findings of factual guilt or procedures to guarantec the accuracy of the information on which the enforcer relies. Prosecutors cannot be sure of the truth of information on which they base their decision not to press charges or to offer a plea bargain, since no trial has yet determined any fact. Similarly, feleral agencies, often not required to take evidence before they issue stipulation and consent orders, have little certainty about the information they rely upon in making the bargain.

The particularized, private bargaining which goes on inside the correctional facility has other correlates outside the prison, where the criterion on which enforeement bargains are often based is not equality but rather the eapacity of the deviant to reduce the cost of enforcement and the cost of crime as perceived by the enforecrs. Iwards of enforcement discretion are made to those white collar criminals, racketeers, and professionals who can conduct their activities with the least visibility (therefore creating a "cost" of crime perceived to be low) and best organization (threatening a high cost of enforcement). Thus, marginal violators who are least organized and most visible vill end up bearing the full brunt of selective cnforcencnt.

Low visibility of infractions is an advantage for the very large enterprise, for it an afford to conduct its activities with stibtlety and subterfuge and can spread the deleterious effects of crime over many victims. See, e.g., J. Galuraitu, Tue New Industmlat. STate 184-86 (1967) (only the largest automobile maunfacturers are able to avoid overt collusion). This may in part explain the reluctance of law enforcement officials to prosecute white collar crime, and the public's relative indifference to stich crimes, eren though the real cost of such criminality to society may be considerably higher than crime in the streets. See, e.g., A. Bluminero, Criminal Justice xxv (1970): "Our penal sanctions, our law enforcement, and the courts which administer them are in a large measure organized and geared to dealing with the kind of crimes most often and most visibly engaged in by socially marginal strata."

In addition, the better organized the enterprise the greater the potential cost to law enforcers of prosecuting the organization or its members. Professional or habitual criminals are often able to afford expert legal advice, making investigation difficult and threatening long and elaborate trials. They are thereby in a good position to take advantage of bargaining opportunitics. See l'Restoevr's CoMM'N ox LAll ENFoncesent AND THE AdMin. OF JUSTICE, TASK FORCE: TIIE CoURTS 11 (1968). Many large corporations. for example, are relatively immune from prosecution by state goternments due to the prohibitive costs of bringing them to trial. See Carcy, America's Respectable Crime Problem, WAshington MonthLY, April 1971, at 38.

The cost of enforcement may also be affected by the political cost of prosecuting individuals or enterprises with high public status. See, e.g., Eckhardt, Deviance, 'ísibility', and Legal Action: The Duty to Support, 15 Soc. 1roy. 470 (1968) (while there vere relatively equal levels of child support obligations among white and bluc-collar workers, prosecution was carried out against forty-four per ecne of the blue-collar group and only twenty-one per cent of the white collar group); Lemert, The Licensing of Chemical Reprocessing Plants Under the Alomic Energy Act, 29 GEo. WAsil. L. REY. 799 (19G1) (patterns of prosecution avoided socially important and stratcgic industries); l'iliavin \& Briar, Police Encounters with Juveniles, 70 AM. J. Soc. 200 (196i) (police more likely to arrest youths who exhibited lower-class mannerisms or dress).

Particularly vulnerable to prosecution are individuals or groups which are seen as symbols of subversion or crime and which possess little real povier to wage costly legal contests. Examples might include the prosecution of various Black Panthers, the Chicago 7, and Catonsville 9. See J. Shklar, Legalism 213 (1961). 
ments made to correctional officers in the form of money bribes, instead of "legitimate" bargains to maintain order. Thus, because it is difficult under the system of private bargaining to supervise closely the officer who allows prohibited goods or prohibited activities in exchange for illegitimate bribes, the total amount of violation may be far greater than it would have been had every officer fully enforced the rules to the limit of his resources. ${ }^{52}$ Second, private bargaining encourages the maintenance of strong inmate organization, capable of reacting quickly and uniformly. Although held together by bribes and force, the bargaining ability of the entire network, as expressed through its inmate leaders, depends upon maintaining the highest possible threat of disruption and violence by the inmate society. In order for a promise to "keep the lid on" or "keep it cool" to be worth significant trades of custodial largesse, the correctional institution must be made aware of the havoc it is avoiding by bargaining with inmate leaders. It is for this reason that an inability to strike a bargain with the institution or competition among inmate leaders, each promising his inmate "constituents" better deals, may bring on violent tests of credibility. ${ }^{53}$ Third, the use of selective discretion by correctional officers in deciding whom to bargain with may aggravate a sense of injustice felt by inmates who do not enjoy the benefits of discretion. The tensions and suspicions generated in such an atmosphere make even inadvertent action by correctional officers seem to inmates to be instances of purposeful harassment. Sensitivities run high so that decisions by correctional officials which might be accepted were there more direct contact and less feeling of oppression instead prompt over-reaction from many inmates. ${ }^{5.4}$

Rather than contributing to the personal safety of inmates, private bargaining may actually result in more internal violence than if no bargaining were to occur. Competition for leadership and control may provoke minor warfare between factions. ${ }^{55}$ In addition, group-

52. For an important qualification of this point, see note 8 supra.

53. Violence as a test of credibility within an on-going bargaining process is explaincd by Nieburg, Violence, Law, and the Informal Polity, $13 \mathrm{~J}$. CoNfl.tcr Resolurion 192, 195 (1969) (emphasis added):

Force must turn to violence to give itself credibility. The rational goal of a threat of violence is an accommodation of interests; [but] the rational goal of actual vio. lence is . . . establishing a measure of the credibility of future threats . . . .

See also P. Blau, Exchaive and Power in Social Life 251 (1964); McClecry, Commumi. cation Patterns as Bases of Systems of Authorily and Power, in Tinonericil Srudies, supra note 3, at 49 .

54. See, e.g., the account given by inmate Harby Moorc, Systematic Rebellion, in Inside Prison American StYle 53 (R. Minton ed. 1971).

55. See, e.g., the account by inmate Victor Dillion, Inside the Prison Clique, in IN. side Prison AMerican Style 32 (R. Minton ed. 1971). 
ings often form along racial or ethnic lines, increasing the likelihood of gang violence. 50 More significant is the fact that private bargains enable and encourage certain segments of the inmate society to control other segments by force and violence, with full toleration of the correctional staff. 57 Those members of the inmate society with least to bargain not only bear the full weight of official enforcement but are also deprived of protection from the more or less constant but low-level use of force against them by other, more powerful, inmates. ${ }^{58}$

\section{Formal Bargaining as a Solution}

As argued above, private bargains with select inmates work against the goals of rehabilitation, protection from arbitrary punishment, and order. In this section it is suggested that open, formal negotiations with the entire inmate community may achieve these goals more effectively.

Formal bargaining within the correctional institution would entail a redistribution of custodial largesse and a new method of bargaining with the inmate society. Under private bargaining, a significant degree of official tolerance is given to select inmate leaders who in return promise (and threaten) their control over segments of the inmate society; the custodial largesse is distributed by those leaders to other inmates in order to gain cooperation and maintain control.

56. See, e.g., the account by inmate Edward Bunker, I'or Behind I'alls, Hanran's, Feb. 1972, at 39,43 .

57. One of the most tyrannous examples of private bargaining within correctional institutions occurred on the Cummins State Prison Farm in Arkansas, where private bargains with select inmates were officially sanctioned as an explicit policy of the prison administration. In Holt v. Sarver, 309 F. Supp. 362 (E.D. Ark. 1970), the court found that only thirty-five regular staff-eight of them on duty at any single time, and only two on duty at night-" supervised" over 1000 prisoners, with the aid of inmates selected to guard other inmates. "[T]he trusty system as it cxists in Arkansas is sui generis. The trusties run the prison. They not only guard other inmates ... [but also perform] ninety per cent of prison functions." Id. at 373. Judge Henley alluded to the illicit bargaining structures that had grown up within the prison population: "By virtue of their positions of authority and the functions they perform trusties ean make or break rankers .... They can make prison life tolerable or they can make it unbearably hard. They can and do sell favors, easy jobs, and covered positions; they can and do extort money from inmates on any and all pretexts. They operate rackets within the prison [and] lend money .... [They] steal food and other commodities from the insti. tution and sell them to other inmates." The trusty system is "a capitalistic system with some of the worst features commonly attributed to "Malia" techniques in organizcd crime. ... [Trusties] can and frequently do bring unmerited discipline down on the head of rankers by "writing them up' for unsatisfactory work or for refusal to work." Id. at $\mathbf{3 7 5}$.

58. There does not seem to exist honor anong thicres. When a broad elass of profitable activity is classified as a crime, the small operators find themselves wholly vulnerable to the larger ones. See, e.g., the discussion of the growth of organized crime in D. BEu, The END OF IDEOLOGY 138 (1960). 
A highly selective process of bargaining thus brings about a vertical distribution of custodial largesse and results in hierarchical relationships within the inmate society. In contrast to private bargaining, formal bargaining would distribute a lesser but relatively more equal amount of official tolerance to all inmates. Bargaining would occur between the correctional administration and the entire inmate population. Relationships within the inmate society would thus be more nearly horizontal, because inmates ivould not be so completely dependent on leaders for access to custodial largesse. The power balance between institution and inmates within the formal bargain would not undergo any radical change as the system moved away from private bargaining. The inherent limitations upon the correctional institution's ability to enforce total regimentation and society's insistence upon a certain degree of order would remain the same. The ability of the inmate society to summon this level of autonomy and freedom from institutional regulation, formerly conditioned upon a hierarchy of internal bribes and force, would now be dependent upon a more collective assessment of possible bargains. Under formal bargaining, in short, the bargaining process between institution and inmates would be made explicit and legitimate.

\section{A. Broad Institutional Changes}

The move from private to formal bargaining within the correctional institution would require two broad institutional changes, both aimed at reducing the incentives for correctional officers and inmates to enter into private, particularized negotiations. In the first place, the bargaining process would have to be broadened and formalized so that all members of the inmate society have access to the information, goods, and freedoms that make up the substance of the bargain and inmates have less need to rely on leaders for custodial largesse. This would, in turn, significantly reduce the ability of inmate leaders to promise (and threaten) correctional officers with their control over segments of the inmate society. ${ }^{50}$ Secondly, official rules and prohibitions would have to be limited to those which could plausibly be fully enforced with available personnel and custodial resources. ${ }^{00}$ The less

59. See, e.g., Mcclecry's study of prison management in transition from a fairly hierarchical and authoritarian administration to a more liberal one in which com. munication channels were opened up with prisoncrs. McClecry, Communication Palterns as bases of Systems of Authority and Power, in Theorerical Studies, supra notc 3, at 49.

60. The structuring of formal bargaining within the prison presents interesting problems in what may be termed "collective bargaining theory." specifically, in order 
serious prohibitions that were never fully enforceable would be eliminated. This would reduce the pressure upon the correctional officer to enter into bargains with particular inmates and eliminate his need to exercise discretion. In addition, because the new rules would be expected to receive full enforcement, the correctional officer could more easily be made answerable for any failure to enforce them. ${ }^{01}$

\section{B. Specific Bargaining Models}

The institutional changes necessary to move from private to formal bargaining within the correctional institution will call for bargaining procedures that maximize participation and access to the bargaining and that also help both sides to understand priorities and recognize the capacity of the other side to use force. There may be no set formula for the ideal bargaining procedure, for any final solution will depend upon the particular needs of the institution and the inmate

to avoid a reversion to the "crime tariff" situation in which inmate leaders exploit their monopoly of access to certain illegitimate goods, services, and activities, it will be necessary both to broaden access to the newly permitted activities and amenities and to enforce strictly non-access to those areas that remain prohibited. So long as the newly negotiated rules can be more or less fully enforced with available administrative and enforcement resources, pay-offs to the innate leadership for additional "help" in enforcing rules will be unnecessary; so long as goods, services, and activities which are no longer prohibited are made generally available, the crime tariff will be further eroded. But it is quite possible that exploitative inmate leaders vould argue for 2 broader range of prohibitions as a way of re-constructing their basis of povier. The paradoxical result may be that administrators should negotiate toward limiting prohibitions to what can be fully enforced even though inmate leadership may unge an enlargement of the rules.

A similar phenomenon may be at work in the subtle negotiations that often go on between organized crime and some law-enforcers. Overcriminalizing the law; bejond the capacity of enforcement resources fully to enforce it, makes culorcement discretion particularly valuable when it comes to certain victinless but highly profitable crimimal activities. Enforcers thereby gain a monopoly of access which can be, and ofien is, sold off to the highest bidder. The highest bidder, already powerful and vell-organized, reaps even greater advantages from the monopoly of access because he can charge much higher prices by distributing the illicit goods to a larger public.

61. Correctional officers might have some role in the formal bargaining process in those cases where their special concerns-such as security in the event of prison riots and general safety-would be dealt with. It is interesting to note that correctional officers are the one group now within the institution that normally engages in formal as viclt as private bargaining, but their formal bargaining efforts are directed at the prison administration rather than at inmates. Guards' unions have demanded and received concessions from correctional administrators that have a direct bearing on the lives of inmates, although inmates have not been parties to the formal negotiations. As examples, in the wake of the Attica rebellion, Security Council 82, which represents about 8,000 New York State correction officers, demanded segregation of the "six to ten per cent of the prison population that is "incorrigible" into a separate institution." The Statc has agreed to study the proposal. N.Y. Times, Sept. 23, 1971, at 66, col. 1. In a related but carlier move after inmate riots at New York City's Tombs and the Queens House of Detention in 1970, New York's Correction Officers Benevolent Association demanded and received a commitment from the City that in future riots there would be no negotiations with inmates until hostages were released and that troops would be sent in immediately to quell disturbances and retake the hostages. N.Y. Times, Feb. 28, 1972, at 62 , col. 1. 
society. Nonetheless, a variety of organizing models is available, and though those to be discussed here are by no means exhaustive, they have in fact been recently used with some degree of success.

The democratic union model, employed in several experiments with inmate self-government, ${ }^{62}$ legitimizes the collective organization of inmates and the election of inmate representatives. For example, during the past year at Washington State Penitentiary inmates drew up a constitution and elected their own Resident Government Council composed of eleven inmates elected for six-month terms. Members of the Resident Government Council negotiate directly with prison administrators. ${ }^{63}$ So that leadership will not fall back into the hands of the most powerful and tyrannical members of the inmate society, democratic controls such as open meetings, secret ballots, and outside

62. One fairly common example of a limited move toward self-government is the usc of "honor units" for inmates who do not require heavy supervision. In fact, honor units within many correctional institutions came about as a response to limitations upon enforcement resources. By segregating those inmates who had most successfully main. tained "clean time" over some period, enforcement resources would be frecd to concentrate on the others. See C-UNrr, supra note 45 , at 98 . But the idea of "inmate selfgovernment" is not a new one. During the early years of the Walnut Street Jail in Philadelphia, beginning around 1793, prisoners established most rules for internal or. ganization of the prison. Punishment for rule violations was "exclusion from the socicty of fellow prisoners," which was found to be "sufficient" to maintain order. Sec K. Lewis, The Develorment of American Prisons and Prison Customs 1776.1845, at 97 (1922). By 1888, the Michigan Penitentiary had pioneered a "Mutual Aid League" in which inmates drew up the constitution, had regular meetings, and decided upon some prison rules. The result, according to the Warden, Hirman Hatch, was a "favorable record of prison discipline." See Helfman, Antecedents of Thomas Mott Osborne's Mulual Welfarc League in Michigan, $40 \mathrm{~J}$. Am. Inst. Crim. L. \& Crimmolocy 597, 599 (1950). Then, in December of 1913, Thomas Mott Osborne founded the "Mutual Welfare League" al the Auburn Prison in New York State, with its primary principle that inmates must work out rules for governing themselves. The Warden handed over most infractions of discipline to the League. When Osborne became Warden of Sing Sing in 1914, lic organized another League there. For a rather idealistic history see " $\mathrm{T}$. OsuONNE, SocieTy" AND PRisons 12, 23, 24 (1916). Apparently, however, the "Mutual Welfare League" at Sing Sing was not all Osborne had hoped for. With hindsight, one might conclude that the formal bargaining that Osborne envisioned disintegrated into private bargaining. See F. Wines, Punishment and Reformation: A Study of the Penitentiary System 78 , 122,397 (1923). The principle of genuine collaboration or joint responsibility for prison management between inmates and staff first found full expression at the Norfolk, Massachusetts, l'rison, where the famous "Norfolk Plan" was inaugurated in 1927. There, inmates and staff formed a single "community government." See Gill, The Norfolk State Prison Colony at Massachusetts, 22 J. AM. InsT. CRiM. L. \& Coiminotoci 107 (1931).

These experiments continued through the 1950 's. But within them inmates had a progressively less important role to play in the actual managing of the institutions, most often becoming "advisory councils" to the warden, informing him of inmate gricvances and desires. See Dickson, Fenton \& Holzschuh, The Inmate Advisory Council, 1955 PROc. OF THE AM. CoRr. Ass'N 142. In short, control devolved upon private bargains. Occasionally private bargaining was made explicit: certain inmate "trusties" were officially selected to fulfill the control function. See, e.g., Holt v. Sarver, 309 F. Supp. 362 (E.D. Ark. 1969). For a more general discussion of the history of schemes for inmate self-government see Baker, Inmate Self-Government, 55 J. CriM. L.C. \& P.S. 39 (1964).

63. See Turner, Democracy is Easing the Life of Inmates at Walla Walla Prison, N.Y. Times, Oct. 18, 1971, at 24, col. 1. See also Newsweek, Nov. 1, 1971, at 26. 
observers are used. ${ }^{64}$ In related experiments, inmate organizations have allied themselves with groups outside the prisons in an effort to add legitimacy and increase public awareness. ${ }^{05}$ The recently formed United Prisoners Union, combining a membership of present inmates with former inmates and inmates' families, has already given its support to several prison strikes and negotiations within California prisons. ${ }^{66}$ At New York State's Green Haven Prison, inmates have formed a union with the stated aim of negotiating wages, hours, and working conditions within the prison and have asked to be affiliated with legitimate labor unions on the outside. ${ }^{07}$ In a similar development in Sweden, inmate councils have joined a national organization of ex-prisoners and community groups in broad-based negotiations with Sweden's centralized correctional administration. ${ }^{88}$

64. The beginnings of the Washington State Penitentiary experiment and the gradual development of democratic controls are documented in Garabedian, The Natural History of an Inmate Community in a Maximum Securily Prison, 61 J. CRIM. L.C. \& P.S. 78 (1970).

65. Obviously, public awareness of inmate needs and grieiances an be an important means of getting political leaders and correctional administrators to respond. Inmates, however, have had no regular channel for making their needs known to the public and few means of educating the public to the problems of incarceration. Public awareness of prison conditions and concern for doing something about the prisons increases only during major prison riots, and then the public is normally divided between those who want to liberalize conditions and those who wish to build stronger fortresses. Inmate organizations allying themselves permanently with outside groups may open up channels for communication and create an on-going public rolc in internal prison affairs.

66. The United Prisoners Union claims a membership of over three thousand inmates and former inmates, and is now recruiting new members in New York, Mlichigan, Ohio, and Pennsylvania prisons. The union has evolved a list of demands for reform which include elimination of the "escalating practice of prison brutality"." an end to the segregation of prisoners because of political belief, and the right of peaceful dissent without reprisals. N.Y. Times, Sept. 26, 1971, at 74, col. 1. See also Editorial, Jailhouse Bargaining, INDUSTRIAL WORKER 2 (May 1971).

67. The Prisoner's Union at Green Haven Correctional Facility has notified the State Correction Commissioner and the prison superintendent that it wants to be the "exclusive bargaining agent" for the inmates. According to W'illiam E. Hillerstein, of the Prisoners' Rights Project of the New York Legal Aid Socicty, more than half of the 1800 prisoners at the prison have signed membership petitions to join the union. Although lawyers for the incipient group defend its Iegitimacy under the Public Employee's Fair Employment Act (Taylor Law), spokesmen claim in addition that the union would provide "a responsible bargaining unit for the inmates (which) could lead to improved prison conditions." The constitution of the prisoners union states that they will seek "through peaceful and lawful means" to equalize to the fullest cxtent possible "the rights, privileges and protections of prison labor with those of free labor everywhere" and to "advance the economic, political, social, and cultural interests" of the prisoners at Green Haven. Inmate organizers have asked to be affiliated with District 65, Distributive Workers of America. Mr. David Livingston, president of District $6^{5}$, said that if the prisoners affiliated with his union an organizer vould be assigned to them and the outside labor union would try to mobilize support for their efforis. N.X. Times, Feb. 8, 1972, at 1, col. 2.

68. KRUMI, the national organization of cx-prisoners and community groups, has taken an active part in negotiating better conditions within Sweden's prisons in the wake of several prison strikes beginning in 1969. According to the Director General of the National Correction Administration, the negotiating machinery has "placed on equal footing the delegates of the country's five thousand prisoners on the one sice and representatives of the correctional authorities and personnel organizations on the other.". 
The mediation model for formal bargaining relies upon specially trained third-parties who possess the skills necessary to articulate the goals of inmates and correctional administrators so that both groups can understand the other side's priorities and concerns..$^{00}$ Skilled mediation, cutting through rhetoric of frustration and fear on both sides, may be able to focus on the specific needs of inmates and officials far more sharply than could face-to-face negotiations. ${ }^{70}$ The mediators may provide inmates with more legitimacy than they would have in direct negotiations and may also serve as a vehicle for airing grievances in public. ${ }^{71}$ In addition, by conducting private interviews with large numbers of inmates, mediators may be able to gain a more subtle understanding of inmate needs than could otherwise be expressed in elections or large meetings. ${ }^{72}$ Of course, some controls would be necessary to assure that mediators respond to the needs of all inmates rather than only to inmate leaders. .Permanent ombudsmen have already been recommended for California, New York, and Oregon prisons, ${ }^{73}$ and the American Civil Liberties Union has recently launched a national effort to install ongoing mediators within a dozen institutions. ${ }^{74}$

B. Martinsson, Prison Democracy in Sweden 37 (1971). See also Jepsen, Krim, Krum, Krom, 4 Prison SERvice J. 28 (1971); Rutherford, Formal Bargaining in the Prison: In Search of a New Organization Model, 2 Yale Rev. L. \& Soc. Ac. $10^{\circ}$ (1971).

69 . For a more precise description of the techniques necessary for successful inediation in circumstances where both sides lack a formalized institutional structure for resolving differences, see T. KHEEL \& L. KADEN, REPORT OF THE BOARD OF Mediation yok Con. Munity Disputes (May 1971); G. Latte, Community Crisis Intervention-Issues and Perspectives, 1970 (mimeo.); L. Kaden, Negotiation and Mediation in Public Employment and Community Conflict, 1971 (mimeo).

70. See, e.g., the suggestions in Whyte, Building Better Organizational Models, in

Essays in Industrial Relations Theory 109 (G. Somers ed. 1959).

71. See note 65 supra.

72. Some of the weaknesses of elections and large meetings as a means of expressing inmate grievances and needs, in terms of rhetoric, crowded and noisy bargaining ses. sions, and play-acting on behalf of constituents on both sides, is artfully revealed in Hough, $A$ Day at the Racists: Diary of a Prison Negotiating Session, BostoN Akte* DARK 2 (Special Supp. 1971).

73. Several recent attempts have been made to install permanent ombudsmen withitı correctional institutions. A bill pending before the California legislature would create a correctional ombudsman whose responsibility it would be to receive complaints from inmates and deal directly with administrators in resolving them. At the Oregon State Penitentiary, a permanent ombudsman has been appointed to receive grievances and resolve tensions between inmates and staff. See Hearings on Corrections Before Subcomm. No. 3 of the House Comm. on the Judiciary, 92d Cong., 1st Sess. (Nov. 11, 1971) (Statement of Linda R. Singer, Executive Director, Center for Correctional Justice). The New York City Board of Correction also recommends the appointment of an oni. budsman in each prison to provide an outlet for prisoners" "legitimate grievances." N.Y. Times, Feb. 4, 1972, at 1, col. 1. See generally Symposium, the Ombudsman or Citizen's Defender: A Modern Institution, 377 ANNals 1 (1968).

74. The A.C.L.U. project at the Great Meadow Correctional Facility in Comstock, New York, features volunteer lawyers on permanent call who are admitted to the in. stitution to listen to prisoners' grievances and negotiate with wardens. The A.C.L.U. plans to use the project as a model which will be attempted in various other states. N.Y. Times, Dec. 19,1971 , at 33 , col. 1 . 
The problem-solving model has become a third strategy for formal bargaining. Under this approach, small groups of inmates and staff specifically charged with developing rules for dealing with certain kinds of conflict exist as on-going problem-solving bodies. Within their areas of concern, the groups issue guidelines and attempt to deal with specific infractions as they arise, thus combining rule-making and adjudicatory functions. Each group includes all persons who have special interest in or concern for the problem area. ${ }^{75}$ Needless to say, such a flexible arrangement has severe limitations when negotiations are carried on with a relatively large inmate population; but for the smaller institution, problem-solving groups may be the best vehicle for assuring broad access and frank discussion. For example, problemsolving groups have served as the main focus for negotiations at Norfolk $^{76}$ and Walpole ${ }^{77}$ prisons in Massachusetts in the wake of prisoner strikes at those institutions in the fall of 1971.

\section{Formal Bargaining and Correctional Goals}

For a number of reasons, it is likely that formal bargaining will better achieve the goals of rehabilitation, protection from arbitrary punishment, and institutional order than does private bargaining. But conclusions in this area must necessarily be tentative. Formal bargaining is still in its initial stages at several institutions, and success is difficult to measure.

\section{Rehabilitation}

If "rehabilitation" is thought of solely as inculcating the dominant values of a given society, formal bargaining may offer little more than private bargaining. ${ }^{78}$ But if by "rehabilitation" we mean pro-

75. One difficulty with this model is that within small, flexible groups of inmates and staff the focus is likely to turn from solving problems external to the group to dealing with the problems of inmates within the group. Milicu therapy of this kind is a far cry from negotiations over different goals, and may permit staff nembers to exert subtle manipulation and control. See, e.g., C-UNrT, supra note 45; A. Rutherford, Inmate Decision Making About the Use of Time, May 3, 1971 (mimco. from Cambridge Institute of Criminology).

76. At the Norfolk Prison, fifteen inmate committees were established following a week of strikes and disturbances. Each committe negotiates a specific aspect of inmate demands. N.Y. Times, Oct. 1, 1971, at 21, col. 4.

77. At Walpole prison, nine such committees have been cstablished. Intervicy with Jim Eisenberg, special assistant to Peter Goldmark, Massachusctts Department of Human Resources, Nov. 21, 1971.

78. Rehabilitation with the aim of changing goals regards deviance as a type of social "disease" that needs to be cured, or a "problem" to be dealt with by trained professionals. It is sometimes assumed that the process of changing the deviant's goals so that they are less in conflict with society's values is more humane than mercly locking 
viding skills which enable an inmate in some measure to satisfy his wants with a minimum of violence, then formal bargaining may bc an important rehabilitative device for a number of reasons. First, in contrast to private bargaining, where inmates learn that bullying and brute force pay off, ${ }^{70}$ formal bargaining rewards negotiation and compromise. Through formal bargaining, inmates may learn how to solve problems, maximize gains, articulate goals, develop alternativc strategies, and deal with opponents without resorting to force or vio. lence-techniques and skills directly applicable to lawfully satisfying their wants outside prison walls. ${ }^{80}$ Second, unlike private bargaining, in which deals are illicit and the inmate's deviant self-image is reaffirmed, ${ }^{81}$ formal bargaining legitimizes many of his goals and interests and provides him with an official means for achieving them. Thus, through formal bargaining the inmate may gain some degree of dig. nity and self-respect, achievements which are also important for getting along outside prison. ${ }^{82}$ Third, formal bargaining may encourage a sense of responsibility and participation. While under private bargaining inmates are often dependent for amenities upon a hierarchical system of rewards, ${ }^{83}$ and getting along in prison is conditioned upon

him up or banishing him. See, e.g., B.F. SKInNER, Beyond FreEdom ANd Dignity 83 (1971). But the process of changing the deviant's goals may do him a greater injustice than simply recognizing the conflict between his goals and socictal valucs and dealing with that conflict explicitly. See generally N. Kirtrie, THE RIGHT To BE DIFFERENT: Deviance and ENforced Theraly (1971); T. SZAsz, IDEolociY AND INSANitY (1970).

In contrast to this view of rehabilitation, formal bargaining diminishes the difference between social deviance and political marginality. The bargaining process regards the conflict between what the deviant wants and what society wants in explicitly political terms, and thereby grants some status and legitimacy to the deviant's goals. Rather than aiming at changing those goals, rehabilitation within a formal bargaining context is directed more specifically to substitution of relatively peaceful means for the more violent means that had been used previously. See Horowitz \& Liebowitz, Social Deviance and Political Marginality: Toward a Redefinition of the Relationship between Sociology and Politics, 15 Soc. Problems 280 (1968). Given the growing perception by many inmates that they are victims of political oppression, formal bargaining may be a more appro. priate vehicle for dealing with deviance than treatment aimed at changing goals. "The latter will increasingly be perceived as a means of disguising legitimate political dif* ferences.

79. See note 50 supra.

80. See Galliher, Training in Social Manipulation as a Rehabilitative Technique, 17 Crime \& Delinquency 431 (1971).

81. See note 49 supra.

82. Legitimizing certain goals, and providing inmates with a degrec of frectom and autonomy to manage their own lives, has been recognized by the courts as a fundamental part of any rehabilitative program. In Barnet v. Rodgers, 410 F.2d 995, 1002 (D.C. Cir. 1969), it was noted that "[t]reatment that degrades the inmate, invades his privacy, and frustrates his ability to choose pursuits through which he can manifest himsclf and gain self-respect erodes the very foundations upon which he can prepare for a socillly useful life," and that it was important to provide the inmate with areas of conduct in which "the inmate may reclaim his dignity and reassert his individuality."

83. See note 38 supra. 
taking orders and not questioning authority, ${ }^{84}$ within the formal bargain inmates would be encouraged to examine institutional policies and take initiative in negotiating change. Attitudes of self-confidence and the skills of critical judgment, important when the inmate leaves the prison to carve out a new life for himself, could in part be developed within the process of formal bargaining. ${ }^{85}$

\section{Protection from Arbitrary Punishment}

By legitimizing and making explicit the balance of power between the institution and its inmates, formal bargaining would result in the creation of new institutional rules that, unlike the present rules, ${ }^{80}$ could be more fully enforced with existing custodial resources. Under private bargaining, the official rules and disciplinary hearings are often unrelated to the actual operating rules and determinations of guilt, which depend upon decisions by correctional officers and inmate leaders. When enforcement resources are inadequate to enforce all the rules and officers are aware of a great deal of minor rule violation, the real locus of rule-making and adjudication is within the officer's personal discretion. By limiting institutional prohibitions to rules that can be fully enforced, formal bargaining shifts rule-making and adjudication away from the personal discretion of officers toward forums where fair and accurate application of the rules can better be assured. ${ }^{87}$ Under formal bargaining, guilt would be determined by procedures designed to find fact; such facts could be made a matter of public record, and decisions could be reviewed or appealed. ${ }^{88}$ In

84. See, e.g., the contrast between conventional treatment environments and new innovative environments in which patients genuincly share power in R. RuuEsisters \& H. Lasswell, The Sharisc; of Power in a Psychiatric Hosutal (1960). Sce also BettelHEIM, supra note 6 , at 137 .

85. One of the most eloquent pleas for respecting the independence and judgment of inmates came from the elected inmate Ieader at the negotiations in the Walpole Prison: "You've had your chance, and you've failed. We want a chance now to change this system. Keep your walls; build them three hundred feet high if you want to; put a dome over the place. Only let us change what happens inside your valls." Quoted in Hough, $A$ Day at the Racists: Diary of a Prison Negotiating Session, Boston AFter DARK 3 (Special Supp. 1971).

86. See pp. 742-43 supra.

87. It is still possible, however, that administrators will condone certain discrimina. tions that seem on their face to be unreasonable and certain other decisions that treat like cases differently on the basis of an assessment by the treatment staff. See W'hceler, Legal Justice and Mental Health in the Care and Treatment of Deviants, in OrmioISYCHIATRY AND THE LAw (M. Levitt \& B. Rubenstein eds. 1968). But with formal bargaining, any discriminations in enforcement could be observed and commented upon by the inmates; such enforcement policies would be the subject of negotiations betreen inmates and administrators within the ongoing process of refining the rules.

88. Formal negotiations could determine the procedural safeguards required before certain penalties could be administered for rule violations. For the most serious penalties, the inmate and administration negotiators could, for example, be guided by court 
addition, formal bargaining could provide fair notice of the rules that would actually be enforced, thus affording a greater measure of predictability and uniformity to life in the institution.

\section{Institutional Order}

By far the greatest obstacle to moving from private to formal bargaining is the fear expressed by administrators and the public that inmates organized collectively pose a greater threat to institutional order, inmate safety, and general security. ${ }^{80} \mathrm{But}$ that fear ignores the alternative form of inmate organization that formal bargaining would replace-a society held together by internal bribes and force, often led by its most violent and criminally mature members, and capable of destructive mass action. ${ }^{90}$

Formal bargaining may undermine the violent inmate leadership fostered by private bargaining. The most powerful inmates, capable of controlling, bribing, and directing others, will have a lesser amount of custodial largesse to dispense when that largesse is formally, and more uniformly, doled out. For this reason it would seem that the most powerful and violent inmates would have less of an incentive to drive hard bargains under formal bargaining than they have under private bargaining. Furthermore, under formal bargaining their power would also be undermined. Because custodial largesse would be dis. tributed to everyone and because power relationships, between the inmates and the institution would be made explicit, leaders would have less with which to bribe correctional officers. ${ }^{91}$ Finally, while

decisions, such as Clutchette v. Procunier, 328 F. Supp. 767 (N.D. Cal. 1971), which called for (1) seven days' notice of the charge, (2) a right to call witnesses and crossexamine adverse witnesses, (3) the presence of an adequate counsel-substitute, (4) decisions based solely on the evidence adduced at the hearing, (5) decisions by fact.finders not involved with the alleged incident, (6) written findings of fact, and (7) uniform notice of any right to appeal. The desirability and feasibility of such safeguards would, of course, have to be determined in light of constitutional requirements as well as a variety of practical considerations relating to the effect of these safeguards on other goals of the correctional institution. Cf. pp. 731-34 supra. In any event, for the admin. istration of less serious penalties inmates and administrators might develop a range of alternative procedures.

89. See, e.g., N.Y. Times, Sept. 14, 1971, at 30. col. 1; id., Sept. 17, 1971 at 31, col. 1. Unlike the hierarchical organization which characterizes the inmate socicty under privatc bargaining and which is hardly visible to the public, formal bargaining is by its very nature highly visible, and the collective organization of inmates is a reminder that the institution cannot force total regimentation upon its inmates. It is quite possible that such visible evidence of inmate power will create public demands for more cffective custody and bring forth public funds for that purpose, thus reducing the bargaining power of inmates within formal negotiations.

90. See note 38 supra.

91. See, e.g., McCleery, Communication Patterns as Bases of Systems of Atthority and Power, in Theoretical Studies, supra note 3 , at 74. 
private bargaining summons the most violent and criminally mature inmates to positions of leadership, under a formal bargaining process more moderate inmates would have an opportunity to participate and have some influence on the bargain. ${ }^{22}$

Formal bargaining may also provide inmates with a legitimate and responsive channel for expressing grievances and demands. According to Vernon Fox, who investigated over two hundred prison riots, major disturbances occur most often when the inmates have sufficient mornle and motivation to take some action for change but are unable to organize and channel that action peacefully and constructively, ${ }^{03}$ either because administrators refuse to respond or because the inmates lack any vehicle for communicating their needs. The closed and repressive inmate society created in part by private bargaining prevents open communication of grievances. ${ }^{94}$ Formal bargaining, on the other hand, may provide inmates with a channel for airing grievances and gaining official response. It may thus give the institution a kind of safetyvalve for peaceful, rather than violent, change. ${ }^{05}$ Furthermore, the atmosphere of suspicion and distrust and the sense of injustice among inmates occasioned by private bargaining may be substantially reduced when the bargain is formalized.90

Formal bargaining may also contribute to the safety of inmates. Selective discretion by correctional officers which characterizes private bargaining creates tensions within the inmate society that threaten the personal safety of many inmates. ${ }^{97}$ By contrast, formal bargaining in which custodial largesse is distributed more evenly and existing rules are more fully enforced may reduce the violent competition for leadership and control, since there would be less reason to com-

92. In McGleery's study of transition in one prison, open communication patterns permitted new, moderate leadership to take over within the inmate socicty. MeClecry, id.

93. V. FoX, Vlolence Behind Bars 308 (1950).

94. Fox, Why Prisoners Riot, 35 FrD. PROB. 9 (1971).

95. In contrast to the violence of Attica, the protests which followed two vecks later at Norfolk and Walpole Prisons in Massachusetts were relatively peaceful. One reason for the lack of violence in Massachusetts was the overtly political tactics used by prisoners there to get their demands across and the fact that information about the strike was allowed to flow freely from the inmates to the public. N.Y. Times, Oct. 3, 1971, at 60 , col. 1. Striking prisoners paraded before television cameras, interrogated prison officials at conferences that the officials opened to the press, and elected committees to negotiate reforms with administrators at a public conference. According to John MI. McCambridge, a leader of the Walpole strike, "all we wanted to do was demonstrate our unity with the implicit threat that this prison-or any other prison-can only run with our consent." N.Y. Times, Oct. 3, 1971, at 60, col. 1 .

96. See p. 744 supra.

97. See Pp. 744-45 supra. 
pete. ${ }^{98}$ In addition, because formal bargaining would create less incentive for inmate leaders to control segments of the inmate society, the internal force and violence often required to sustain control would be minimized. ${ }^{99}$ Finally, since formal bargaining will not permit correctional officers to enter into private, particular bargains, they will have no reason to tolerate the low-level use of force and terror within the inmate society which they have often tolerated under private bargaining. ${ }^{100}$

\section{Conclusion}

The real effects of formal bargaining as an explicit means of sharing power within prisons and other total institutions can, of course, only be speculated upon. ${ }^{101}$ Experiments with formal bargaining should

98. At Washington State Penitentiary, tension between the races seems to have becn reduced since inmates were given a significant degree of autonomy. N.Y. P'ost, Nov, 1, 1971, at 35, col. 1 .

99. See note 59 supra.

100. Under private bargaining, the weakest members of the inmate socicty are doubly liable-to full enforcement of the then existing rules and to "under the surface" force and violence against them from the more powerful inmate leadership. In contrast, under formal bargaining the new prohibitions would be more nearly fully cnforccable against all inmates, and because most inmates desire to be secure from violence, it might even be feasible to prohibit all direct assaults by one inmate against another-even minor assaults which would have been tolerated when "surface order" was the operating goal of official enforcement. In this way, formal bargaining may enable inmates to use the official mechanisms of control for some of their own ends.

101. It would be difficult to spell out in detail the implications of this discussion for other total institutions and for communities in which the role of law-enforcer approximates the enforcement role within prisons, but some general remarks are in order. When a significant shortage of enforcement resources relative to known violations creates an incentive on the part of enforcers to bargain with select violators in an attempt to reduce the overall level of violation-whether in the form of plea-bargains with prosecutors, bargains not to prosecute in return for information, bargains not to harass in return for exerting control over others, or other types of private bargain-it might well be argued that such private bargaining has detrimental effects. Specifically, such bargaining may (1) make individuals vulnerable to arbitrary decisions by cnforccrs concerning whom to "go after." As in the prison, members of the community who can offer the law-enforcers information or ability to control segments of the community or who can threaten to cost law-enforcers large amounts of enforcement rcsources in apprehension and conviction, gain the best bargains. (2) Private bargaining may con. tribute to social violence by permitting the most organized criminal to profit from his monopoly of access to certain illicit but highly profitable activities and goods, such as prostitution, gambling, and drugs. Because of their organization, and becatise law. enforcers can rarely be made to answer for their exercise of discretion, illegitimate bribes may earn the well-organized criminals even greater degrees of immunity. The organized criminals often protect their monopoly of access by violent means and further their system of marketing goods and collecting debts by violence. (3) Finally, private bargaining may contribute to a sense of powerlessness, alienation, and injustice on the part of those who must bear the full weight of official discretion and unofficial violence. Such alienation may express itself in more criminal activity and violence.

It would be too facile to suggest that some variant of formal bargaining is the appro. priate remedy for all of these related ills. But within total institutions like prisons and in relatively closed communities where law-enforcement resources are far from being able to enforce the law fully, some form of negotiated rule-making might alleviate the problems. Institution of community rule-making with enforcers participating would 
continue in prisons, mental hospitals, schools, and other captive environments where institutional policies designed to achieve behavioral changes conflict with institutional requirements for maintaining order, and where the legal process is typically unable to protect inmates from the subtleties of arbitrary punishment. Restructuring inmate power, by bargaining formally with all inmates rather than privately with a few, may contribute toward maximizing these difficult and often incompatible goals.

specify what laws will and will not be enforced, and to what cxtent. The rule-making would establish standardized plea-bargains and bargains not to prosecute or enforce that would be uniform for all members of the institutions or the community and would create procedures for appealing breaches of agrecd-upon rules. Professor Davis urges similar rule-making proceedings:

If a choice can be freely made between full fidelity to enacted law and police illegality through a rule specifying what will and will not be enforecd, the enacted law: clearly should prevail. But realistically, that choice is not open to the police if the community refuses to tolerate full enforcement, as many communities do, and if the legislative body refuses to amend the statute, as many do. If the only realistic choice for the police is between 1) secret policies through ad hoc decisions of individual officers, often resulting in flagrant denials of equal justice, and 2) open policies adopted through rule-making proceedings with something approaching cien application in all like cases, then the second choice is clearly better than the first. K. Davis, Discretionary Justice 93 (1969). 